\title{
The Dilemma of Democracy: Collusion and the State of Exception
}

\author{
MARK MCGOVERN \\ Department of Social Sciences, Edge Hill University, United Kingdom
}

\begin{abstract}
In what sense might the authoritarian practices and suspension of legal norms as means to combat the supposed threat of "terrorism," within and by contemporary western democratic states, be understood as a problem of and not for democracy? That question lies at the heart of this article. It will be explored through the theoretical frame offered in the work of Giorgio Agamben on the state of exception and the example of British state collusion in non-state violence in the North of Ireland.

The North of Ireland provides a particularly illuminating case study to explore how the state of exception-the suspension of law and of legal norms and the exercise of arbitrary decision-has increasingly become a paradigm of contemporary governance. In so doing it brings into question not only the traditional conceptualization of the "democratic dilemma" of liberal democratic states "confronting terrorism" but also challenge dominant paradigms of transitional justice that generally fail to problematize the liberal democratic order.

After outlining Agamben's understanding of the state of exception the article will chart the development of "exceptional measures" and the creation of a permanent state of emergency in the North, before critically exploring the role of collusion as an aspect of counter-insurgency during the recent conflict. The paper will argue that the normalization of exceptional measures, combined with the need to delimit the explicitness of constitutional provision for the same, provided a context for the emergence of collusion as a paradigm case for the increasing replication of colonial practices into the core activity of the contemporary democratic state.
\end{abstract}

\section{Introduction: The Dilemma of Democracy}

In Terrorism and the Liberal State (1986) renowned British counter-insurgency theorist Paul Wilkinson provides a classic description of what mainstream "terrorist experts" construe as the fundamental democratic dilemma facing the modern "liberal state" confronting "terrorism":

The primary objective of counter-terrorist strategy must be the protection and maintenance of liberal democracy and the rule of law. It cannot be sufficiently stressed that this aim overrides in importance even the objective of eliminating terrorism and political violence as such. Any bloody tyrant can "solve" the problem of political violence if he is prepared to sacrifice all considerations of humanity, and to trample down all constitutional and judicial rights. (p. 125)

When such "counter-terrorist" strategies are enacted within the context of "emergency powers," debate tends to focus on one of two options; either upholding

Correspondence Address: Mark McGovern, Department of Social Sciences, Edge Hill University, Ormskirk, Lancashire L39 4QP, United Kingdom. Tel.: +44 (0) 1695 584621;

Email: mcgoverm@edgehill.ac.uk

ISSN: $1911-4788$ 
"constitutional provisions" or prioritizing "the democratic principles underpinning the constitution rather than the strict letter of the constitution itself" (Campbell \& Connolly, 2003, p. 345-346). In either case, as Connolly and Campbell, suggest, the "end-goal [of] preserving democracy" provides the un-problematized ultimate justification for the policies pursued (p. 346). There is a convenient circularity to such arguments, founded on the a-priori acceptance of the self-legitimating theories of the liberal democratic state itself. Modern liberal democracy and the "rule of law," seen as essentially synonymous and mutually re-enforcing, are presented in supposedly "objective" terms, as a mode of governance and judicial order that need to be maintained and protected.

However, there may be an alternative way of conceptualizing this "dilemma" (if that is how it should be understood) as one not for but of contemporary democracy. Rather than being located as a problem whose origin lies in the threat of violence posed to the state, this dilemma might rather be sited as one inherent in the character of modern democracy itself, the idea of the rule of law and the relationship of both to the state's use of organized violence.

It is such an alternative conception of a democratic dilemma that this paper seeks to explore. It will do so by looking at British state collusion in non-state violence during the conflict in the North of Ireland. This record of collusion, it will be argued, casts light on a deeply embedded and dark dimension of the character and practice of the modern democratic state; namely the increasingly normalized role of the state of exception. The Italian philosopher Giorgio Agamben $(1998,2005)$ has provided telling insights into the significance of the state of exception for understanding the workings of modern liberal democracies. This analysis of the meaning of collusion for the contemporary democratic order will therefore be informed by the work of Agamben as it will at the same time provide a means of exploring the central tenets of his argument through the case of British state collusion during the Northern Ireland conflict.

The paper will be divided into 5 parts. Part 1 will set out what is meant by collusion and why the study of these "death squads" operating in a democratic state is important. Part 2 will explore what Agamben means by the state of exception and why he argues that it is of such significance for understanding the modern democratic state as a juridical order. Section 3 will examine the role of the state of exception in the development of the Northern Irish state from its inception through to the 30 years of conflict (1968-1998) and beyond. Part 4 will examine the interaction of the state of exception, British state counter-insurgency theory and practice and the strategy of collusion. Finally, the character of collusion as a practice precisely shaped by a "void of law" (Agamben, 2005, p. 26) will be explored further through the lens of the paradigmatic example put forward by Agamben, the iustitium of ancient Roman law.

\section{Collusion, Transition and Democracy}

\section{Death Squads, Democracy and Transition}

Linked to the need to deconstruct Wilkinson's democratic dilemma, two key academic concerns have informed this analysis of the meaning of collusion for 
liberal democracies. First, the general absence of such analyses in the academic study of death squads and (second) the tendency to conflate post-conflict transition with a shift toward democracy.

Death squads are understood as "paramilitary groups involved in state-sponsored or state-tolerated terror against political opponents" (Rolston, 2006, p. 181) and as Bill Rolston has argued, the involvement of democratic states in the operation of such groups is conspicuous by its virtual absence from academic literature on the subject (see also; Campbell \& Brenner, 2002; Sluka, 2000, Woodworth, 2002). This is all the more surprising given the "deniability" such covert organized violence offers regimes for whom there may be a greater political cost to pay for public knowledge of their actions. Nor is it coincidental that this parallels the virtual absence of the study of western democracies' involvement in "state terrorism" (Chomsky, 2004; George, 1991; Jackson, 2008; Stohl, 1984, 2006). Even critics of democratic states that have employed death squads tend to argue that democracy is a necessary, if insufficient condition to prevent such mass human rights violations (Green \& Ward, 2004). The issue of death squads and collusion needs therefore to be more fully explored precisely for what it reveals about the nature of the modern democratic state and its relationship to "terror" and "terrorism."

In similar vein, the conceptualisation of post-conflict transition, and the means to address the legacies of past political violence and mass human rights abuses, particularly as it is understood within the field of transitional justice, tends to be shaped by what has been called a "paradigm of transition" (Ní Aoláin \& Campbell, 2005). Such a paradigm constructs a series of antinomies (the transition from "peace to war," from "denial to acknowledgement") as if they were synonymous with that from "authoritarianism to democracy." Western-style democracy emerges, as a result, as the pre-ordained end-goal of transition.

Apart from anything else, as Ní Aoláin and Campbell (2005) have suggested, this tends to preclude the analysis of what they refer to as "conflicted democracies"; states that have witnessed mass human rights violations (including those perpetrated by the state) where the very institutions and practices promoted as the means to prevent such state violence singularly failed to do so. The problem of contemporary western democracies engaging in mass human rights abuses is similarly understood solely as an aberration of their character, rather than something that may be of their essence.

In this sense, the "paradigm of transition" shares the same conceptual terrain as the logic of the "liberal peace" and "military humanism" that have come so much to the fore as the means to justify western intervention and military expansion in the "War on Terror" during the last decade. It is therefore unsurprising that this mainstream "transitional justice" agenda has emerged as a cornerstone of contemporary global governance and "state-building" (Chandler, 2006; Duffield, 2007).

\section{Collusion and Conflict in the North of Ireland}

What then is collusion? Collusion here is understood as the involvement of state agents, directly or indirectly, through commission, collaboration or connivance, in 
non-state political violence. Such collusion can take a variety of forms. The report of the Stevens Inquiry ${ }^{1}$ understood collusion to include the "wilful failure to keep records, the absence of accountability, the withholding of intelligence and evidence, through to the extreme of agents being involved in murder" (Stevens, 2003, p. 16). Retired Canadian Judge Peter Cory, who conducted a series of inquiries into allegations of collusion, adopted a deliberately broad definition of collusion because:

Army and police officers must not act collusively by ignoring or turning a blind eye to the wrongful acts of their servants or supplying information to assist them in their wrongful acts or encouraging them to commit wrongful acts. Any lesser definition would have the effect of condoning, or even encouraging, state involvement in crimes, thereby shattering all public confidence in these important agencies (Cory, 2004, pp. 21-22).

Both Stevens and Cory concluded that collusion was "widespread and systematic" (Stevens, 2003). Taken alongside other official and non-official inquiries (see for example, Cassels, 2006; O'Loan, 2007) and belying the "rotten apple" theory so often proffered by those defending the role of the British state in the North, these findings suggest collusion took place throughout the 30 years of conflict, over a wide geographical area and potentially involved hundreds of victims.

While some hold that such public inquiries demonstrate the efficacy of democratic institutions to uphold accountability and end impunity there is a need to treat such claims with caution (Ignatieff, 2005). Rather we might see such a process as one where there is a move from literal and interpretive to implicatory forms of denial (Cohen, 2001, pp. 7-8). Public inquiries (and the limitations within which they operate) themselves play an important role in continuing to obfuscate the fundamental character of state violence undertaken by contemporary democracies, just as they are held up as a post-hoc legitimization of the democratic state itself (Burton \& Carlen, 1979; Rolston \& Scraton, 2005)

There is, in other words, a need to deconstruct the polar opposition of "authoritarianism" and "democracy" and to explore the issue of collusion more thoroughly by subjecting to scrutiny and critique the very nature of the modern liberal democratic state. It is within this context that the work of Giorgio Agamben on the role of the state of exception in contemporary democratic state practice can be useful.

\section{The State of Exception}

\section{The Significance of the State of Exception}

For Agamben the state of exception is crucial for understanding the paradigm of modern governance and fundamental to the western political and legal tradition upon which the character and practice of contemporary "so-called democracies" are based (Agamben, 2005, p. 3). Indeed, Agamben's argument is specifically designed to challenge liberal conceptions of the origins and nature of the legitimacy of contemporary democratic states in late capitalism; namely that such legitimacy derives from a tradition of adherence to a set of legal norms that are certain, predictable and guarantee a range of minimal freedoms in opposition to the 
arbitrary exercise of governmental power. Rather than a genealogy of the contemporary liberal democratic state that foregrounds the role of the social contract and of rights, Agamben sets out to explore what (following Carl Schmitt) is understood as the basis of sovereignty, "the sovereign is he who decides on the state of exception" (Carl Schmitt, 1922, quoted in Agamben, 2005, p. 1).

For Agamben the state of exception is one that involves the suspension of law and of legal norms and the exercise of arbitrary decision. He argues that it is pivotal for understanding the nature of contemporary state practice and of "lifting the veil" on the "ambiguous zone... [the] no-man's land between public law and political fact" (Agamben, 2005, pp. 1-2) for two main reasons.

First, Agamben (2005) argues that the state of exception is the "original structure in which law encompasses living beings by means of its own suspension" (p. 3). For Agamben this is deeply historically embedded in the western political tradition. Following Foucault, Agamben suggests this represents a form of bio-political power but, unlike Foucault, he finds its origin predates the modern. Rather, "the inclusion of bare life in the political realm constitutes the original-if concealednucleus of sovereign power... the production of a bio-political body is the original activity of sovereign power" (Agamben, 1998, p. 6).

What is distinctive about the modern state is that it places the regulation of biopolitical life as explicit to its purpose and in so doing "bring[s] to light the secret tie uniting power and bare life" (Agamben, 1998, p. 6). In many ways identifying this lineage from the ancient to the modern is one of the key genealogical tasks of Agamben's work. It also provides the logic for his exploration of apparently obscure figures and archetypes (such as homo sacer and the iustitium) found in ancient (particularly Roman) law as a means to explore the contemporary.

Second, Agamben holds that the state of exception as the "voluntary creation of a permanent state of emergency (though perhaps not declared in the technical sense) has become one of the essential practices of contemporary states, including socalled democratic ones" (Agamben, 2005, p. 3). Writing against the backdrop of the "Global War on Terror" Agamben contends that the state of exception is increasingly the "dominant paradigm of government in contemporary politics" (Agamben, 2005, p. 3).

Crucially too, while he is at pains not simply to conflate the two, the increasing reliance on the state of exception as a technique of governance calls into question the (all too politically and ideologically significant) juxtaposition of totalitarianism and democracy as distinct constitutional forms. The space between "public law and political fact" opened up, for example, by the status of the detainee in Guantanamo Bay, and his reduction to the condition of "bare life," is one in which the "state of exception appears as a threshold of indeterminacy between democracy and absolutism" (Agamben, 2005, p. 3).

\section{The "State of Exception," the "State of Necessity" and the Intensification of State Power}

The state of exception is also significant because it is the limit of the juridical order. Rather than being identified as either "inside" or "outside" the juridical order (as different legal traditions would have it) Agamben wants to deconstruct this 
"simple topographical opposition" and to argue instead that the state of exception should be conceived as a "threshold, or a zone of indifference... where inside and outside... blur with each other. The suspension of the norm does not mean its abolition and the zone of anomie that it establishes is not... unrelated to the juridical order" (Agamben, 2005, p. 23). This characterization of the state of exception as a "zone of indistinction," an "anomic space" and a "void of law" can provide a language through which to capture and represent state practices (such as that of collusion) that lie at one and the same time apparently beyond and yet inextricably bound up with the juridical order.

As well as providing an evocative conceptualization of the fluid and indistinct character of the anomic space that is the state of exception, Agamben's analysis of two strands within western legal traditions, and their interaction with the changing character of the state through the twentieth century, also provides important insights. One tradition (prevalent in France and Germany) makes specific constitutional or legal provision for the regulation of the state of exception. The other (evident in "England" and the USA) consists of states "that prefer not to regulate the problem explicitly" (Agamben, 2005, p. 10).

That said, Agamben (2005, p. 10) contends that the distinction between the two, "clear in principle but hazier in fact" has done little or nothing to prevent "something like a state of exception" developing in all of the identified western state orders since the early twentieth century. Indeed, the term state of exception, readily found in French and German legal traditions has its direct equivalent in the "English tradition"; "martial law" or "emergency powers."

Justification for the state of exception and the suspension of legal norms is invariably founded on arguments of necessity; that exceptional powers must be introduced, and rights suspended, so that the democratic order may be preserved. Indeed such an argument can be seen to lie at the heart of the terrorist experts' democratic dilemma in posing the question - what aspects of democracy must we give up in order to preserve democracy?

Legal concepts of necessity (that "necessity creates its own law") can be subject to a range of critiques. Perhaps the most persuasive is that, while claims of necessity tend to be couched in objective terms they are always founded on a subjective decision. As Balladore-Pallieri notes (as cited in Agamben, 2005) the concept of necessity is:

An entirely subjective one, relative to the aim one wants to achieve. It may be said that necessity dictates the issuance of a given norm, because otherwise the existing juridical order is threatened with ruin; but there must be agreement on the point that the existing order must be preserved. (p. 30)

Necessity was presented as the underlying logic justifying the intensification of state power through the twentieth and twenty-first centuries. This involved powers previously evident only in a "real state of siege" (for example, an actual condition of war) becoming a paradigm of governance in peacetime where a "fictitious state of siege" has been enacted (Agamben, 2005, p. 17). Agamben sees the great conflagrations of the twentieth century, particularly the two world wars, as pivotal in this build up of state power. Based on the needs of wartime economies and characterized by the ever-encroaching power of the state over civilian life, the 
transference of wartime conditions to peacetime governance results in the normalization of the state of exception (Agamben, 2005, p. 18).

To illustrate the crucial role of wartime conditions in generating this move toward the permanence of "exceptional measures" in the British case Agamben specifically cites the Defence of the Realm Act (DORA). The DORA was introduced in August 1914 and did indeed massively expand the direct power of the state over the lives of citizens. It also provided the template for the emergence of such "exceptional measures" as a norm in peacetime Britain. This was even more obviously the case in Ireland.

\section{Ireland and "Exceptional Powers"}

\section{Colonialism and the State of Exception}

Agamben's (inevitably constrained) reading of the factors involved in the emergence of the state of exception becoming a paradigm of modern governance can be critiqued for the virtual absence of the influence of colonialism. Of course, the impact of colonialism on the colonized, and on the subsequent development of the 'post-colonial' state, is crucial for understanding the experience of the contemporary in large parts of the world. Indeed, it could be argued that the reduction of the experience of the colonised to 'bare life' was part and parcel of an imperial juridical order and fundamental to shaping modern bio-politics.

The experience of empire also had a transformative effect on the imperial polity itself, most obviously perhaps in terms of culture and representation (Said, 1993), but also in the transposing of colonial forms of governance and practice into the institutionalized order of the modern state. A recent analysis of the development of the foundational doctrines of international law, and particularly the sovereignty doctrine itself, argues that colonialism (rather than being a peripheral factor, as conventional analyses suggest) were "forged out of an attempt to create a legal system that could account for relations between the European and non-European worlds in the colonial confrontation" (Anghie, 2005, p. 3). That non-European societies could be conceived by European jurists as being void of sovereignty, a consequence of their imagined incivility and barbarism, could allow for the state of exception to become a norm of imperial governance. It may also have inured the apparatchiks of empire to techniques of government that, with some modification, could be translated into practices within the modern mass democratic state itself.

In this context Ireland may provide a crucial case study. In many ways Ireland lay at another, territorial and jurisdictional threshold, as a colonised society that was also (from the Act of Union onward) subject to incorporation into the body and boundaries of the colonising state. Indeed the condition and place of Ireland, as both inside and beyond the bounds of the British state, might be conceived as a jurisdictional space of indeterminacy parallel to the juridical space and "zone of indistinction" that is the state of exception itself. This borderland, threshold Irish experience of British governance and use of force is one that may therefore have significant implications. 


\section{From "Special Powers" to "Emergency Powers"}

To chart the process whereby the "voluntary creation of a permanent state of emergency" became an "essential practice" of the British state it is necessary to look to Ireland. As Adrian Guelke (2007) recently argued, "for more than a century the Irish Question played a central role in the justification of emergency security measures in the United Kingdom outside actual periods of inter-state war [italics added]" (p. 273). Taking Agamben's example as a starting point, the DORA provided a direct template for legislation introduced in Ireland in the period of the Irish Revolution (1916-1921), most obviously in the Restoration of Order in Ireland Act (ROIA) of 1920 .

However, both the DORA and the ROIA need to be seen against the backdrop of the 105 Coercion acts introduced in Ireland by the British state between the introduction of the Act of Union in 1801 and partition in 1922 (see Ainsworth, 2001; Campbell, 1994; Townsend, 1983). Coercion Acts were measures introduced by the British state to suppress political and agrarian unrest in Ireland and, as Charles Townsend (1983) notes, the DORA "gave the executive the sort of powers previously heralded by emergency legislation like the Protection of Person and Property Act [of 1881]" (p. 280). Ireland was also the only part of the Union in which martial law had been in force, following the 1798 Rebellion and the first years after the Act of Union and, again, in various parts of Ireland between 1916 and 1922.

Indeed the period of the Irish Revolution was crucial for the development of the modern British state's amalgamation of mass democracy with the state of exception. As the then Chancellor Austen Chamberlain privately mused on the question "can modern democracies handle such problems successfully?" (as cited in Townsend, 1983, p. 353), in an ominous forerunner of things to come, his cabinet colleague Winston Churchill argued that the way to defeat Sinn Fein was to introduce a policy of "gunning" rather than "burning" and to "let the police get at the gunmen whom they knew but could not legally convict [italics added]" (Townsend, 1983, p. 352).

The militarization of policing was evidenced in the creation of auxiliary units of the Royal Irish Constabulary (the infamous "Black and Tans") and subsequently, following the creation of the Northern Ireland state by the Government of Ireland Act (1920), in the form of the Special Constabulary (or "B" Specials) (see Farrell, 1983). The formation of the "B" Specials (whose structure, personnel and ethos were all framed by the pre-existing loyalist paramilitary Ulster Volunteer Force) was one part of the establishment of a permanent state of exception as the norm for the new state. In legislative terms this was exemplified by the Civil Authorities (Special Powers) Act of 1922.

The Special Powers Act (as it became known, SPA) was again closely modelled on the DORA and the ROIA and would remain in force throughout the period from 1922 to 1973 . The SPA symbolises what Laura Donohue (2007) recently described as the "temporary permanence" of emergency legislation in the North, or what (more accurately) Paddy Hillyard (1993) termed the "normalization of special powers."

The direct antecedent (as we shall see) of later exceptional measures and the foundation of the "architecture" of contemporary special ("anti-terror") powers, the

Studies in Social Justice, Volume 5, Issue 2, 2011 
SPA is also remarkable in representing perhaps the most explicit instance of constitutional provision for the state of exception in the "English" legal tradition. In this context, some of the expansive and exceptional powers given over to the executive (in this case the Unionist Northern Ireland Government) by the SPA are worth noting. The SPA made permanent (certainly after 1933) wide ranging powers of detention (including internment, or arrest without charge and imprisonment without trial); entry, search and seizure; the prohibition of meetings and processions and censorship and banning of publications and organizations. They were also powers that, contrary to received academic wisdom, were widely and regularly used (Donohue, 2007).

In addition to these specific draconian powers the SPA also gave the executive two, apparently all-encompassing, general provisions. First, that the civil authority could take "all such steps and issue all such orders as may be necessary for preserving the peace and maintaining order" (as cited in Donohue, 2007, p. xix). Second (notable for its Kafka-esque quality, instrumental vagueness and potentially retrospective application) that:

If any person does any act of such a nature as to be calculated to be prejudicial to the preservation of the peace or maintenance of order in Northern Ireland and not specifically provided for in the regulations, he shall be deemed guilty of an offence against the regulations. (Donohue, 2007, p. 23)

It is difficult to imagine a clearer example of the legal provision of a state of exception. Significantly too as the undoubtedly turbulent and violent circumstances that accompanied the North's establishment receded, the "state of necessity" arguments advanced by the North's permanent Unionist regime to justify its exceptional powers shifted from being notionally "necessary in order to establish order" to "necessary in order to maintain peace" (Donohue, 2007, p. 23).

The SPA was a prime target for the civil rights agitation of the late 1960s that ultimately (given the state's reaction) led to the conflict that lasted from 1968-1998 and cost some 3,600 lives. The SPA itself was ended in 1973, following the introduction of direct British government control of the North. However, far from an end of "special measures," the SPA was immediately replaced by the Northern Ireland (Emergency Provisions) Act (EPA). Rather than abnegating the authoritarian powers contained in the SPA (for example, internment) the EPA enshrined and further embedded them.

Indeed, in certain key areas (such as rules governing the eligibility of evidence and the creation of no-jury courts) the legal due process was substantially subverted to counter-insurgency ends (Greer \& White, 1986; Hadden \& Hillyard, 1973; Jennings, 1990; Walsh, 2000). Along with the introduction in 1974 of the first Prevention of Terrorism (Temporary Provisions) Act (PTA) and a series of additional measures this would ensure the incorporation of the state of exception as an "essential practice" of British governance. As Paddy Hillyard has suggested (see McGovern, 2010) with the EPA and the PTA the 'architecture' of contemporary counter-insurgency law and policy was put in place. 


\section{Emergency Powers, Counter-insurgency and the Problem of the Explicit Exception}

\section{Colonialism and Counter-Insurgency Theory}

The explicitness of the "special powers" evident in the North of Ireland presented the British state with a conundrum that was reflected in the counter-insurgency theories and practices employed following the outbreak of the conflict. The loose body of writings that made up British counterinsurgency theory at that time had been developed within the context of its various "end of empire" struggles waged against national liberation movements in places like Malaya, Palestine, Aden, Yemen and Kenya (Dixon, 2009; Newsinger, 2002. See also, Clutterbuck, 1967; Kitson, 1960, 1971; Paget, 1967; Thompson, 1967). In many ways the application of such theories to part of the jurisdiction of the metropolitan state itself evidenced the impact of the colonial on the operation of the modern liberal democratic juridical order.

Yet to openly adopt the (in fact highly coercive) "hearts and minds" strategies employed elsewhere in the colonized world revealed a central paradox for the British state. Such a step made explicit not only the state of exception but also the colonial condition of the North of Ireland that its inclusion in the jurisdiction and constitutional order of the Union, and the rhetoric of the Government, was specifically designed to deny. Indeed, it was precisely the suggestion that a supposed colonial condition existed that the struggle against Irish republicanism, the state's principle enemy, was specifically intended to negate.

The problem, in other words, might be understood as one that was far less with the practice of the state of exception than with its potentially becoming all too apparent. It was this problem, the preservation of the self-projected legitimacy of the liberal democratic state, with which the adaption of counter-insurgency policy and practice was designed to deal. The explicitness of a constitutional or legal provision for the state of exception (as Agamben noted) runs contrary to the English legal tradition. However, as he also argues, that has had little material impact on the exception becoming the norm. In similar vein the development of alternative counter-insurgency models need to be explored in this context.

Contemporary counter-insurgency (or "counter-terrorism") theorists make analytical distinctions between three main approaches to "tackling terrorism"; a "war model," a "criminal-justice" model and a "reconciliatory" model (Pedahzur, 2010). The first identifies terrorism as a form of warfare and places the emphasis on a military response. The second presents terrorism as a criminal problem and emphasises the role of the police and criminal justice system while a reconciliatory model considers terrorism as a political problem and sees a solution through political negotiation.

Yet as even ardent advocates of counter-terrorism suggest, these models are more distinct in theory than in practice, are far from mutually exclusive and often operate in tandem. Revealingly Ami Pedahzur (2010) also notes that "if the struggle against terrorism takes place beyond the borders of the democratic state, policymakers are apt to worry less about limiting their methods to constitutionally approved ones and tend to favour the war model" (p. 1). 
An analogous three-part typology has recently been proposed, ostensibly to describe different phases of the conflict in the North of Ireland and their significance for the "War on Terror" (Guelke, 2007). For Guelke, British counterinsurgency can be understood in terms of an initial "militarization" (late-1960s to mid-1970s, followed by "criminalization" (mid-1970s to early 1990s) and "accommodation" (the peace process of the 1990s and after). That said, though these strategies are "rarely pursued simultaneously" Guelke (2007) also argues that they are not "entirely watertight compartments" and that "while proclaiming a stance of criminalization, a government may covertly pursue policies that are consistent with suppression, such as a policy of targeted assassinations or a "shootto-kill' policy" (pp. 275-276).

Counter-insurgency strategies in the North in the early 1970s, symbolized by events such as the Falls Curfew (1970) the introduction of internment (1971) and Bloody Sunday (1972) certainly looked very much like a "war model" (Campbell \& Connolly, 2003). This period was also marked by the highest levels of direct deaths (particularly of civilians, disproportionately from the catholic/nationalist community) for which the British army and state forces were responsible (McKitterick, Kelters, Feeney, Thornton, C., \& McVea, 1999; Ní Aoláin, 2000). It is also true to say that the onset of a "criminalization" strategy, signalled by the introduction of the EPA, the PTA and other measures, did represent a shift in counter-insurgency thinking.

However, as we have already seen, far from adapting to the conventions of the criminal justice order, this strategic shift rather involved the subversion of legal norms to counter-insurgency ends. If the adoption of a criminal justice model meant anything it was far less to ensure counter-insurgency actions "were restrained by the state legal system" (Pedahzur, 2010, p. 1) than the criminal justice system was reshaped to render counter-insurgency practices "legal." Or as the oft-quoted dictum of the counter-insurgency theorist Frank Kitson (who served in a key role in the North in the early 1970s) expressed it, one alternative for counter-insurgency practice is that:

The law should be used as just another weapon in the government's arsenal, and in this case it becomes little more than a propaganda cover for the disposal of unwanted members of the public. For this to happen efficiently, the activities of the legal services have to be tied into the war effort in as discreet a way as possible. (Kitson, 1971, p. 69)

The other alternative Kitson offers, echoed in the interpretations of the "criminal justice" model favoured by defenders of British policy in the North, is that, even if draconian measures are introduced (which might in any case constitute a normalization of the state of exception) the law remains "impartial... the officers of the law will recognise no difference between the forces of the government, the enemy or the uncommitted part of the population...Anyone violating the law will be treated in the same way" (Kitson, 1971, p. 69). The question must then be posed, is this what happened? And if not, how might we best understand and conceptualise this dimension of contemporary liberal democratic juridical order and practice? 


\section{Counterinsurgency, Collusion and the Iustitium}

\section{Counter-insurgency, Criminalization and Collusion}

Frank Kitson was himself instrumental in creating covert British military units in the North in the early 1970s that were alleged to be involved in a number of shootings and killings. The Military Reaction Force (MRF) was created under his command in 1971, though it was soon reorganized and replaced by the Special Reconnaissance Unit (SRU) in 1972, which operated under the cover name of the $14^{\text {th }}$ Intelligence Company (Dillon, 1991, p. 29-32). These were forerunners of a series of covert units within the British army, military intelligence, police force and special branch that would conduct the state's "dirty war" in the North through the following decades. Far from becoming less significant with the shift to "criminalization" in the mid-1970s such covert operations became the defining feature of state practice. This involved a number of inter-related developments.

The police force itself was increasingly militarized. Always an armed force the Royal Ulster Constabulary (RUC) also created a number of special counterinsurgency units, some of which were involved in the "shoot-to-kill" policies of the 1980s. In line with the strategy of "Ulsterization," there was a growing reliance on locally recruited forces, most obviously in the form of the Ulster Defence Regiment (UDR). Almost exclusively drawn from the Protestant community, a significant number of UDR members would be deeply implicated in allegations of collusion, particularly in rural border areas. The Special Air Service (SAS) was deployed from the mid-1970s onward and was also allegedly involved in a number of covert killings (Murray, 1990; Urban, 1992). In addition further covert military intelligence units were created that, alongside elements of the police Special Branch, were at the forefront of developing collusion as state practice.

Collusion came in a range of guises, from the relatively ad hoc efforts of individual members of state agencies passing information and weapons on to (primarily loyalist) paramilitary groups, to forming part of an overall counterinsurgency strategy directed by key personnel within the state security apparatus. It also came more to the fore in the latter stages of the conflict, particularly from the mid-1980s onward, as allegations of a shoot-to-kill policy undertaken directly by state covert agencies in the police and army became increasingly public.

Certainly from the mid-1980s onwards loyalist violence increased significantly which meant that, by the early 1990s, they were responsible for more conflict victims annually than anyone else (Ní Aoláin, 2000). Allegations that state agencies were deeply implicated in this rise in loyalist violence have centred on the activities of both RUC Special Branch and a covert British military intelligence unit known as the Force Research Unit (FRU) (Larkin, 2003; O'Brien, 2005; Relatives for Justice, 1995; Rolston, 2006).

The activities of the FRU (particularly their alleged involvement in the killing by loyalists of human rights lawyer Pat Finucane in 1989) have been the subject of a great deal of scrutiny (Cory, 2004; O’Brien, 2005; Rolston, 2006). The FRU was formed in 1980/1981 and was the primary military intelligence body responsible for handling British agents in paramilitary organizations. It is alleged to have been involved in a number of murders as well as providing intelligence files and 
facilitating the importation of a large cache of weapons from South Africa used by loyalists in over 200 killings (RFJ, 1995).

The collusion activities of FRU came to light following the inadvertent arrest in 1992 of their agent, Brian Nelson, who doubled as the intelligence officer of the loyalist Ulster Defence Association in West Belfast. During his trial Nelson's record (which included involvement in several murders) was defended by the head of FRU, who it later emerged was Colonel Gordon Kerr. Kerr has since gone on to serve as a commander of covert units as part of the British forces occupying Iraq and Afghanistan.

While the various inquiries into collusion have led to several arrests and convictions the vast majority of these have been of loyalist paramilitaries rather than members of the state forces. Certainly none have been of any of significant rank, command or influence. This reflects the pattern of non-arrest and nonconviction that typified cases where state agents were directly responsible for conflict-related killings (CAJ, 1983, 1990, 1992). Between 1969 and 1998 there were a total of 376 deaths caused directly by members of the British Army and the RUC. However, only four soldiers have been convicted of murder and one for manslaughter while no member of the RUC has ever been convicted for using lethal force (Walsh, 2000, p. 266-7).

\section{Understanding Collusion: The Meaning of the "Iustitium"}

Within the narrative of the democratic dilemma, the sort of covert state violence described above is understood as either the consequence of a state of necessity or (if being found to have too obviously transgressed constitutional norms) an aberration of, and exception to, democratic state practice. However, if understood through the lens of the state of exception, we might see this rather as an exemplar of the authoritarian capacity of contemporary governance where the need to render the exceptional state inexplicit and deniable requires its covert operation. To grasp the sense and substance of such practices we might also turn to Agamben's "paradigmatic form" and the "miniature model" he puts forward to lift the veil on the "ambiguous zone" that is the contemporary state of exception; the archetype of the iustitium within Roman Law (Agamben, 2005, p. 41).

One of Agamben's key arguments, contrary to that of Schmitt and other jurists and legal theorists, is to oppose the conflation of the state of exception with dictatorship. The adoption of full powers is, he suggests, one possible outcome of the state of exception but the two are not necessarily synonymous. Rather, the defining character of the state of exception is to be found in the indeterminacy and the void of law. In order to illustrate this point Agamben uses the paradigm example of the iustitium.

The iustitium, meaning literally "standstill" or "suspension of the law" (Agamben, 2005, p. 41), was a decree declared by the Roman Senate calling on Magistrates (and citizens) to "take whatever measures they considered necessary for the salvation of the state." Such a proclamation followed the declaration of a "tumultus," an emergency caused by a "tumult that created a particular form of disorder" (Agamben, 2005, p. 42). Such a tumult was not defined either as a state of war or its absence, or in terms of the severity of a threat, but rather in terms of 
the consequent state of affairs to which it led; a condition of profound destabilization to the existent order.

In Agamben's (2005) analysis the declaration of an iustitium precisely did not lead to the creation of a dictatorship (understood as a newly established magistracy specifically designated with sweeping or full powers) but rather resulted in the "production of a juridical void" (pp. 41-42). That void was one that involved the suspension of the laws and legal norms that limited the powers and actions of the agents of the state (magistrates). The specific character of the iustitium was thus not in creating new powers that might justify new actions but in removing the constraints of the normative juridico-institutional order to permit actions that would otherwise be impermissible. This included the protection of the life of the citizen:

[The iustitium was] a matter of, under exceptional circumstances, putting aside the restrictions that the law imposes on the actions of the magistrates... in particular the prohibition... against putting a Roman citizen to death [without orders from the people]. (p. 45)

In these conditions of anomie, Agamben (2005) suggests, the actions taken by the unconstrained magistracy lie in a plane of the "un-decidable" as far as the sphere of law is concerned because "he who acts during the iustitium neither executes nor transgresses the law but inexecutes it... the appraisal of which, once the iustitium is expired, will depend on the circumstances" (p. 50).

If we look at collusion through the lens of the iustitium it emerges not as aberration or the consequence of a "rotten apple," still less as an affirmation of the efficacy of democratic accountability, but rather as an aspect of the suspension of legal norms that marks the state of exception of the modern state. Collusion happens precisely in this "space devoid of law" or "zone of anomie," not through the potentially politically problematic assumption of full powers, precisely because this would make explicit an absolutist condition of the modern liberal democratic state that its own theoretical self-representation seeks to mystify.

Rather, called in the context of a particular kind of "tumult" (signified today by the term terrorism), dependent in turn on the state's subjective decision of necessity, this modern-day equivalent of the iustitium, the covert suspension of the norms and restrictions placed upon the actions of certain state agents, allows for the object of their actions, in this instance the victims of collusion, to emerge as homo sacer, "he who may be killed and yet not sacrificed" (Agamben, 1998, p. 8).

\section{Conclusion: Collusion as a Dilemma of Democracy}

When confronted with the evidence of torture perpetrated by US forces at Abu Ghraib prison, the journalist and broadcaster Christopher Hitchens (an avowed proponent of the war in Iraq) argued that there could only be two interpretations of how it happened (as cited in Žižek, 2008, p. 148). Either those involved in the torture of detainees were acting of their own volition or they had been specifically authorized to do so. However, as Slavoj Žižek (2008) has insisted, this is to miss the point and entirely misunderstand the context within which such acts come to receive a form of social and institutional legitimation. For Žižek the horrors of Abu 
Ghraib were an example of a "code red," an "unwritten rule of a military community that... condones an act of transgression, it is 'illegal' yet at the same time it reaffirms the cohesion of the group" (p. 148). As Žižek notes (citing Agamben) such a military culture takes shape within the context of a state of exception where the suspension of legal norms reduces those subject to such torture as homo sacer.

It also does so in the context of a mythology of the bureaucratized state. The contemporary bureaucratized institutional order presents itself as rigorous, regulated, regularized and rational. Yet as anyone working in such institutional settings know (the contemporary university springs to mind) this hardly adequately captures the social reality of how such institutions work, and how lives are constrained, framed, directed by and lived within them. The capacity for the creation of zones of in-distinction in contemporary institutions, where the formal normative order is adapted, misshaped, subverted and/or suspended, as illustrated by the Abu Ghraib example, describes a condition closer to that reality.

As Agamben points out, when this happens in relation to the juridical order it should neither be understood as occurring simply within or beyond the bounds of that order, but rather in a threshold zone. In the North of Ireland this was the space in which collusion became possible and practiced by agents of the state. The exemplar of the iustitium helps us conceptualize this space of a void of law as the blurred defining limit of the juridical order.

Collusion was shaped by the state of exception becoming the dominant paradigm of governance combined with the British state's need to develop counterinsurgency practice that made that condition inexplicit. Rendering the state of exception deniable and un-representable is central to the legitimating order of contemporary liberal democracy. The long term normalization of the state of exception in the North of Ireland, evident in the genealogy of "emergency" measures, became a more critical issue for Britain when it returned to direct rather than indirect control. As a result the state was more obviously confronted with the pressing need to preserve the appearance of 'constitutional normalcy' (Ignatieff, 2005). The evident incorporation of colonial practice into the juridico-institutional order of the British state presented it with a dilemma of legitimacy rather than of democracy.

Paul Wilkinson (1986) argues that "anti-terrorist policy" must always be under the overall control of the democratically elected government and that "the government and its security forces must at all times act within the law" (p. 128). Significantly the main reasons he proposes for doing so are that the government must be "seen [italics added] to be doing all in its power" to defend citizens and that "flouting the law" undermines state legitimacy because it allows "terrorists and their fellow-travellers [to make] enormous propaganda capital" out of such illegal acts (p. 128).

Yet two other options are available to the state to counter such potential and (for the state) undesirable effects. First, change the law to make what would otherwise be illicit licit, or what would be illegal not seen as such. Second, ensure that illegal acts are not seen at all. When the state of exception becomes a standard form of governance, for the democratic order to regularly resort to such alternatives become a very real dilemma for those subject to such a form of so-called democracy. In this 
sense the real democratic dilemma derives, not from the threat posed to it, but from the nature of the contemporary democratic state itself.

\section{Notes}

1 This was the third official British government inquiry headed by Sir John Stevens (former Head of the Metropolitan Police) into allegations of collusion in a number of high profile killings. Stevens issued a summary of his findings in 2003, though the full report has never been published.

\section{References}

Agamben, G. (2005). State of exception. Chicago, IL: University of Chicago Press.

Agamben, G. (1998). Homo sacer: Sovereign power and bare life (2nd ed.). Stanford, CA: Stanford University Press.

Ainsworth, J.S. (2001). British security policy in Ireland, 1920-1921. Australian Journal of Irish Studies, 1, 176-190.

Anghie, A. (2005). Imperialism, sovereignty and the making of international law. Cambridge: Cambridge University Press.

Burton, F., \& Carlen, P. (1979). Official discourse: On discourse analysis, government publications, ideology and the state. London: Routledge, Kegan \& Paul.

Campbell, B. B., \& Brenner, A. D. (2002). Death squads in global perspective: Murder with deniability (2nd ed.). New York, NY: Palgrave.

Campbell, C., \& Connolly, I. (2003). A model for the "war against terrorism"? Military intervention in Northern Ireland and the 1970 Falls Curfew. Journal of Law and Society, 30(3), 341-375.

Campbell, C. (1994). Emergency law in Ireland, 1918-1925 (2nd ed.). Oxford: Clarendon Press.

Cassel, D. Kemp, S., Pigou, P., \& Sawyer, S. (2006). Report of the Independent International Panel on Alleged Collusion in Sectarian Killings in Northern Ireland. Notre Dame, IN: Center for Civil and Human Rights, Notre Dame Law School.

Cohen, S. (2001). States of denial: Knowing about atrocities and suffering. Oxford: Polity Press.

Chandler, D. (2006). Empire in denial: The politics of state building. London: Pluto Press.

Clutterbuck, R. (1967). The long, long War: The emergency in Malaya, 1948-1960. London: Cassels.

Committee on the Administration of Justice. (1992). Inquests and disputed killings in Northern Ireland. Belfast: CAJ.

Committee on the Administration of Justice. (1990). Cause for complaint: The system for dealing with complaints against the police in Northern Ireland. Belfast: CAJ.

Committee on the Administration of Justice. (1983). Procedures for handling complaints against the police. Belfast: CAJ.

Cory, P. (2004). Cory collusion inquiry report: Patrick Finucane. Retrieved from http://www.nio.gov.uk/cory_collusion_inquiry_report_pat_finucane.pdf.

Chomsky, N. (2004). Pirates and emperors, old and new: International terrorism in the real world. London: Pluto Press.

Dillon, M. (1991). The dirty war. London: Arrow Books.

Dixon, P. (2009). Hearts and minds? British counter-insurgency from Malaya to Iraq. Journal of Strategic Studies 32(3), 353-381.

Donohue, L.K. (2007). Counter-terrorism law and emergency powers in the United Kingdom, 1922-2000 (3rd ed.)Dublin: Irish Academic Press.

Duffield, M. (2007). Development, security and unending war: Governing the world of peoples. London: Polity.

Farrell, M. (1983). Arming the protestants: Formation of the Ulster Special Constabulary and the Royal Ulster Constabulary. London: Pluto Press.

George, A. (Ed.). (1991). Western state terrorism. London: Polity Press.

Green, P., \& Ward, T. (2004). State crime. London: Pluto Press.

Greer, S., \& White, A. (1986). Abolishing the diplock courts: The case for restoring jury trial to scheduled offences in Northern Ireland. London: Cobden Trust. 
Guelke, A. (2007). The Northern Ireland peace process and the war against terrorism: Conflicting conceptions? Government and Opposition, 42(3), 272-291.

Hadden, T., \& Hillyard, P. (1973). Justice in Northern Ireland: A study in social confidence. London: Cobden Trust.

Hillyard, P. (1993). Suspect community: People's experience of the prevention of terrorism acts in Britain. London: Pluto Press.

Jackson, R. (2008) The ghosts of state terror: Knowledge, politics and terrorism studies. Critical Studies on Terrorism, 1(3), 377-392.

Jennings, A. (Ed.). (1990). Justice under fire: The abuse of civil liberties in Northern Ireland. London: Pluto Press.

Kitson, F. (1960). Gangs and counter-gangs. London: Barrie \& Rockliff.

Kitson, F. (1971). Low intensity operations: Subversion, insurgency and peacekeeping. London: Faber \& Faber.

Larkin, P. (2003). A very British jihad: Collusion, conspiracy and cover-up in Northern Ireland. Belfast: Beyond the Pale Publications.

McGovern, M. (2010). Countering terror or counter-productive? Comparing Irish and British Muslim experiences of counter-insurgency law and policy. Ormskirk: Edge Hill University.

McKitterick, D., Kelters, S., Feeney, B., Thornton, C., \& McVea, D. (1999). Lost lives: The stories of the men, women and children who died as a result of the Northern Ireland troubles. Edinburgh: Mainstream Publishing.

Murray, R. (1990). The SAS in Ireland. Cork: Mercier Press.

Ní Aoláin, F. (2000). The politics of force: Conflict management and state violence in Northern Ireland. Belfast: Blackstaff Press.

Ní Aoláin, F., \& Campbell, C. (2005). The aradox of transition in conflicted democracies. Human Rights Quarterly, 27(1), 172-213.

Newsinger, J. (2002). British counter-insurgency: From Palestine to Northern Ireland. London: Palgrave.

O'Brien, J. (2005). Killing Finucane: The inside story of Britain's intelligence war. Dublin: Gill \& Macmillan.

O'Loan, N. (2007). Public statement by the police ombudsman for Northern Ireland on her investigations into the circumstances surrounding the death of Raymond McCord Junior and related matters. Belfast: PONI.

Paget, J. (1967). Counter-insurgency operations: Techniques of guerrilla warfare. London: Faber \& Faber.

Pedahzur, A. (2010). The Israeli secret services and the struggle against terrorism. New York NY: Columbia University Press.

Relatives for Justice. (1995). Collusion 1990-1994: Loyalist paramilitary murders in the North of Ireland. Belfast: Relatives for Justice.

Rolston, B. (2006). An effective mask for terror: Democracy, death squads and Northern Ireland. Crime, Law and Social Change, 44(2), 181-203.

Rolston, B., \& Scraton, P. (2005). In the full glare of English politics: Ireland, inquiries and the British state. British Journal of Criminology, 45(4), 547-564.

Said, E. (1993). Culture and imperialism. London: Chatto \& Windus.

Schmitt, C. (1985). Political theology. Cambridge: MIT Press.

Sluka, J.A. (Ed). (2000). Death squad: The anthropology of state terror. Philadelphia, PA: University of Pennsylvania Press.

Stevens, J. (2003). Stevens inquiry 3: Overview and recommendations. Downloaded from http://www.cain.ulst.ac.uk/issues/collusion/stevens3/stevens3summary.htm.

Stohl, M. (2006). The state as terrorist: Insights and implications. Democracy and Security. 2, 1-25.

Stohl, M., \& Lopez, G. (1984). The state as terrorist: The dynamics of governmental violence and repression. Westport CT: Greenwood.

Thompson, R. (1967). Defeating community insurgency. London: Chatto \& Windus.

Townsend, C. (1983). Political violence in Ireland: Government and resistance since 1848. Oxford: Clarendon Press.

Urban, M. (1992). Big boy's rules: The SAS and the secret struggle against the IRA. London: Faber \& Faber.

Walsh, D.P. J. (2000). Bloody Sunday and the rule of law in Northern Ireland, Dublin: Gill \& Macmillan. 


\section{Mark McGovern}

Wilkinson, P. (1986). Terrorism and the liberal state (2nd ed.). New York, NY: New York University Press.

Woodworth, P. (2002) Dirty war, clean hands: ETA, the GAL and Spanish democracy. New York, NY: Yale University Press.

Žižek, S. (2008) Violence: Six sideways reflections. London: Profile Books. 